\title{
Myxobolus taibaiensis sp. n. (Myxozoa: Myxosporea) infecting the intestinal wall of common carp Cyprinus carpio Linnaeus in China
}

\author{
Xinhua Liu ${ }^{1,2}$, Congjie Hua ${ }^{1,2}$, Qianqian Zhang ${ }^{1}$, Yuanli Zhao ${ }^{1,2}$, Dong Zhang ${ }^{1,2}$ and Jinyong Zhang ${ }^{1}$ \\ ${ }^{1}$ Fish Diseases Laboratory, State Key Laboratory of Freshwater Ecology and Biotechnology, Institute of Hydrobiology, Chinese \\ Academy of Sciences, Wuhan, China; \\ ${ }^{2}$ University of Chinese Academy of Science, Beijing, China
}

\begin{abstract}
Myxobolus taibaiensis sp. n. was found in the inner intestinal wall of common carp, Cyprinus carpio Linnaeus, during the investigation of fish parasite fauna in Lake Taibai, located in the middle reach of the Yangtze River, China. The whitish ellipsoidal plasmodia, up to $2.9 \mathrm{~mm}$ long and $1.7 \mathrm{~mm}$ wide, developed in the circular muscle layer of the intestinal wall and produced significant compression into adjacent tissues, but no significant inflammatory responses were observed against this infection. Mature spores are oval in frontal view and lemon-like in lateral and apical view, averaging 10.2-11.2 $\mu \mathrm{m}(10.8 \pm 0.2 \mu \mathrm{m})$ in length, 9.1-9.9 $\mu \mathrm{m}(9.6 \pm 0.2 \mu \mathrm{m})$ in width and 6.1-6.6 $\mu \mathrm{m}(6.3 \pm 0.1 \mu \mathrm{m})$ in thickness. Polar capsules are pyriform, equal in size, slightly converging anteriorly, measuring 4.4-5.4 $\mu \mathrm{m}(5.0 \pm 0.2 \mu \mathrm{m})$ in length by 3.2-3.6 $\mu \mathrm{m}(3.4 \pm 0.1 \mu \mathrm{m})$ in width. Polar filaments coiled with four to five turns and arranged perpendicular to the polar capsule length, measuring up to $106 \mu \mathrm{m}$. Myxobolus taibaiensis sp. $\mathrm{n}$. is morphologically similar to Myxobolus rotundatus Achmerov, 1956 which also infects the inner wall of the intestine of common carp. However, the small subunit ribosomal DNA sequence identity was only $94 \%$, generally beyond the intraspecies variation in the genus. Phylogenetically, this new species is sister to M. rotundatus and then clusters with M. shantungensis Hu, 1965 to form an independent common carp-infecting cluster within the Henneguya-Myxobolus clade.
\end{abstract}

Keywords: common carp, Cyprinidae, intestine, circular muscle layer, Yangtze River

Myxozoa Grassé, 1970 is an important group of metazoans that mainly infect fishes, but with some species parasitising amphibians, reptiles, birds and mammals (Lom and Dyková 2006, Székely et al. 2016). Approximately 2200 myxosporean species have been so far reported over the world, representing high species diversity (Lom and Dyková 2006). However, some of them were described solely based on spore morphology. Given the incredible diversity along with the simplicity of the taxonomic criteria used to differentiation of these species, it is often difficult to discriminate morphologically similar species using spore morphology alone (Chen and Ma 1998, Liu et al. 2013). To avoid the above conundrum, a comprehensive approach including spore morphology, exact location of sporulation, tissue specificity, host specificity and molecular data has been widely accepted for description of novel species (Fiala 2006, Atkinson et al. 2015).

Common carp Cyprinus carpio Linnaeus is an important commercial fish species that has been cultured for more than 4000 years in China and its annual production has reached more than 300 million kilograms in China in 2013 (Lin et al. 2014). However, epizootic diseases have caused severe economic and environmental problems with the rapid development of intensive aquaculture of this species. Virosis, bacteriosis and parasitoses were increasingly reported to be responsible for the mass mortality of reared common carp (Yokoyama et al. 1997, Zhang et al. 2010, Dong et al. 2013, Zhai et al. 2016). Myxosporidiosis represents one of the most important parasitic diseases of common carp in China. About 85 myxosporeans have been so far described in different tissues and organs of common carp in China (Chen and Ma 1998, Dyková et al. 2003, Liu 2014). However, some watersheds have never been investigated, so the species diversity of myxosporeans is probably underestimated in China.

Lake Taibai is located in the middle reach of the Yangtze River where 46 fish species have been reported and the annual fishery product is approximately 4 million kilograms (Jin 2007). To the best of our knowledge, no myxosporean species have been previously recorded in this natural shallow water lake (Chen and Ma 1998). Therefore, we conducted an investigation of fish myxosporean parasites of this lake to enrich our knowledge of the species diversity. In this paper, a new species is described by combining

Address for correspondence: J. Zhang, Fish Diseases Laboratory, State Key Laboratory of Freshwater Ecology and Biotechnology, Institute of Hydrobiology, Chinese Academy of Sciences, Wuhan, China. Phone: +86-27-68780007; Fax: +86 27 68780720; E-mail address: zhangjy@ihb.ac.cn

Zoobank number for article: urn:lsid:zoobank.org:pub:1A6F0DBF-024F-4A36-98FA-71FB24A2F538 
spore morphology, ecological features and molecular characteristics.

\section{MATERIALS AND METHODS}

\section{Morphological analysis}

Twenty specimens of common carp ranging from $34.5 \mathrm{~cm}$ to $40.5 \mathrm{~cm}$ in total length were collected from Lake Taibai off the lakeside of Huangmei country, Hubei province, China. Fish were transported alive to the local laboratory of aquatic animal diseases in oxygenated plastic bags and temporarily kept in aerated aquaria. Fishe were dissected within 1 to 2 days post capture. Samples of gills, skin, kidney, gallbladder, intestine and other organs were routinely examined to find cyst-like plasmodia under naked eyes, stereomicroscope and phase contrast microscope. If dissected fish were infected with myxosporeans, a single plasmodium was isolated from the infected tissues and ruptured with a fine needle on a slide to make wet preparations for morphological observation. The remaining spores from the ruptured plasmodium were preserved in $95 \%$ ethanol for molecular analysis. Fresh spores were observed and images captured under an oil immersion objective $(1000 \times)$ with an Olympus DP10 digital camera. Measurements were taken from 50 randomly selected fresh spores from 5 plasmodia. All measurements are in micrometres $(\mu \mathrm{m})$ unless otherwise indicated and presented as range (mean \pm $\mathrm{SD}$ ). Some released spores were preserved in glycerine-jelly as reference slide in the laboratory of Fish Diseases, Institute of Hydrobiology, Chinese Academy of Sciences. Additionally, smear slides of mature spores were air-dried and stained with Diff-Quik (NobleRyder, Shanghai, China). Line drawings were made based on the fresh wet mounts and stained slides with the aid of CorelDraw X6 (Corel, Ottawa, Canada) and Adobe Illustrator software (Adobe Systems, San Jose, CA, USA).

\section{Histological examination}

Infected tissue samples containing developing and mature plasmodia were fixed in $10 \%$ neutral buffered formalin, dehydrated in ethanol and embedded in paraffin wax. Tissue sections, 4-6 $\mu \mathrm{m}$ thick, were stained with haematoxylin and eosin (H \& E) and examined under a light microscope (Olympus DP10).

\section{DNA isolation and sequencing}

For DNA extraction, preserved spores in ethanol were centrifuged and washed two times with distilled water to remove the ethanol remnants. Genomic DNA was isolated from tissue homogenates using the Qiagen DNeasy Blood \&Tissue Kit (Qiagen, Germany), following the manufacturer's recommended protocol for animal tissue. The gDNA concentration was determined using a NanoDrop 2000 spectrophotometer (Thermo Scientific, Shanghai, China) at $260 \mathrm{~nm}$.

The partial sequence of the SSU rDNA gene was amplified using a primer pair, MyxospecF (Fiala 2006) and 18R (Whipps et al. 2003) in a $25 \mu \mathrm{l}$ reaction mixture, which comprised $30 \mathrm{ng}$ template DNA, $1 \times$ PCR mixture (CWbiotech, Beijing, China), 10 pmol of each primer. Amplification conditions were initial denaturation at $94^{\circ} \mathrm{C}$ for $4 \mathrm{~min}$, followed by 35 cycles of $94^{\circ} \mathrm{C}$ for $1 \mathrm{~min}, 46^{\circ} \mathrm{C}$ for $50 \mathrm{~s}, 65^{\circ} \mathrm{C}$ for $90 \mathrm{~s}$, with a terminal extension at $65^{\circ} \mathrm{C}$ for $10 \mathrm{~min}$. The PCR products were electrophoresed in $1.2 \%$ agarose gels in Tris-borate-EDTA buffer gel stained with
$1 \%$ ethidium bromide and then purified with a PCR purification kit (CWbiotech, China). The purified product was cloned into PMD-18T vector system (Takara, Dalian, China) and then sequenced with the ABI BigDye Terminator v 3.1 Cycle Sequencing Kit with an ABI 3100 Genetic Analyser.

\section{Phylogenetic analysis}

Sequences were aligned in BioEdit (Hall 1999) and ambiguous bases clarified using corresponding ABI chromatograms. The consensus sequences were deposited in GenBank with accession number KU928249 and verified as myxozoan by BLAST search. To explore the phylogenetic relationships of the present species with related myxobolids, 43 sequences were retrieved from GenBank and aligned using Clustal X 1.8 program (Thompson et al. 1997) with defaulting setting. The data set for alignment consisted of the top BLAST search matches and representatives of neighbouring clades based on earlier analyses of myxobolids (Molnár et al. 2006, Liu et al. 2016a). The alignment was corrected manually using the alignment editor of MEGA6.0 software (Tamura et al. 2013).

Phylogenetic analysis was conducted as follows: Maximum likelihood (ML) analysis and Bayesian analyses (BI) was conducted in PhyML 3.0 and Mr. Bayes, respectively (Ronquist and Huelsenbeck 2003, Guindon et al. 2010). The optimal evolutionary model for maximum likelihood and Bayesian analyses were determined using jModelTest 3.07 (Posada 2008) which identified the best evolutionary model as the general time reversible model $(\mathrm{GTR}+\mathrm{I}+\mathrm{G})$, using Akaike information criteria. Nucleotide frequencies were estimated from the data $(\mathrm{A}=0.2413, \mathrm{C}=0.1927$, $\mathrm{G}=0.2778, \mathrm{~T}=0.2881)$; six rates of nucleotide substitution calculated as $\mathrm{AC}=1.3862, \mathrm{AG}=4.2306, \mathrm{AT}=1.9229, \mathrm{CG}=0.6300$, $\mathrm{CT}=6.0859, \mathrm{GT}=1.000$. The proportion of invariable site was 0.3026 and the alpha value of gamma distribution parameter was 0.3868. Myxidium lieberkuehui Bütschli, 1882 (X76638) and Myxidium truttae Léger, 1931 (AF201374) was used as outgroup. Two independent runs were conducted with 4 chains for 2 million generations for Bayesian analysis. Phylogenetic trees were sampled every 100 generation. The first $25 \%$ of the samples were discarded from the cold chain (burninfrac $=0.25$ ). Bootstrap confidence values were calculated with 1000 repetitions for ML. Trees were initially examined in TreeView X (Page 1996).

\section{RESULTS}

During the survey of myxosporean fauna in Lake Taibai, five species of Myxobolus Bütschli, 1882 were found from the dissected specimens. Among them, Myxobolus koi Kudo, 1919, M. toyamai Kudo, 1917 and M. tsangwuensis Chen, 1954 infected the gills, with infection prevalence of $30 \%(6 / 20), 20 \%(4 / 20), 15 \%$ (3/20), respectively. Coinfection of these three species could be occasionally found. Myxobolus cyprinicola Reuss, 1906 and a suspected new species were found to dwell in the outer and inner intestinal wall, respectively, with prevalence of $35 \%(7 / 20)$ and $25 \%(5 / 20)$. However, no coinfection of these two intestine-infecting species was observed. For the concerned new species, numerous whitish plasmodia were macroscopically visible in the whole intestinal wall after dissecting specimens (Fig. 1A). 

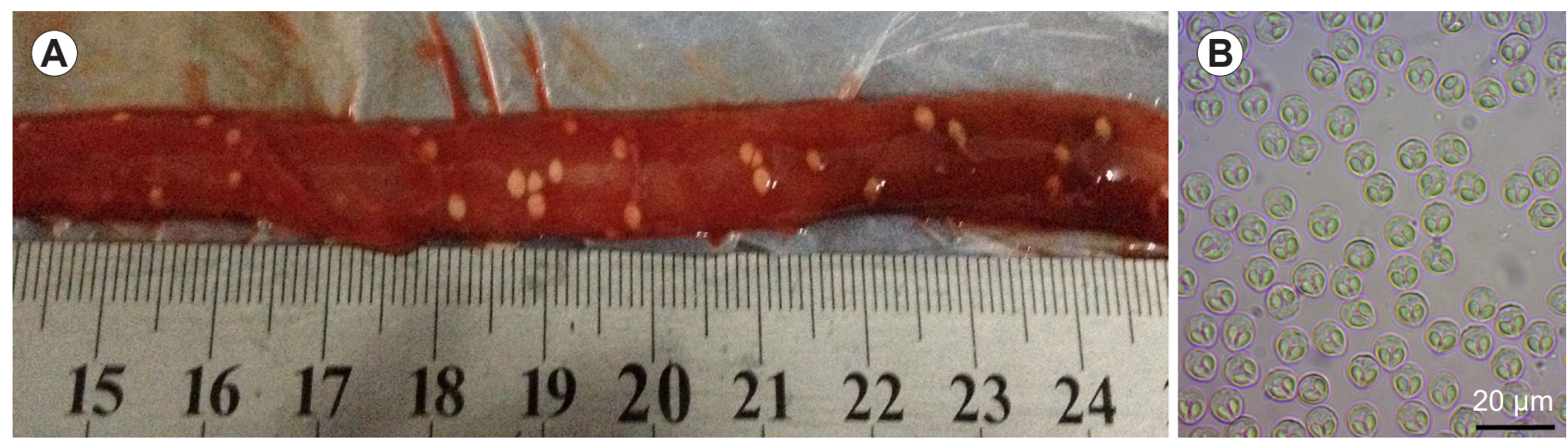

Fig. 1. The plasmodia and spores of Myxobolus taibeiensis sp. n. from Cyprinus carpio Linnaeus. A - numerous plasmodia macroscopically visible in the whole intestinal wall; $\mathbf{B}$ - fresh spores in frontal view.
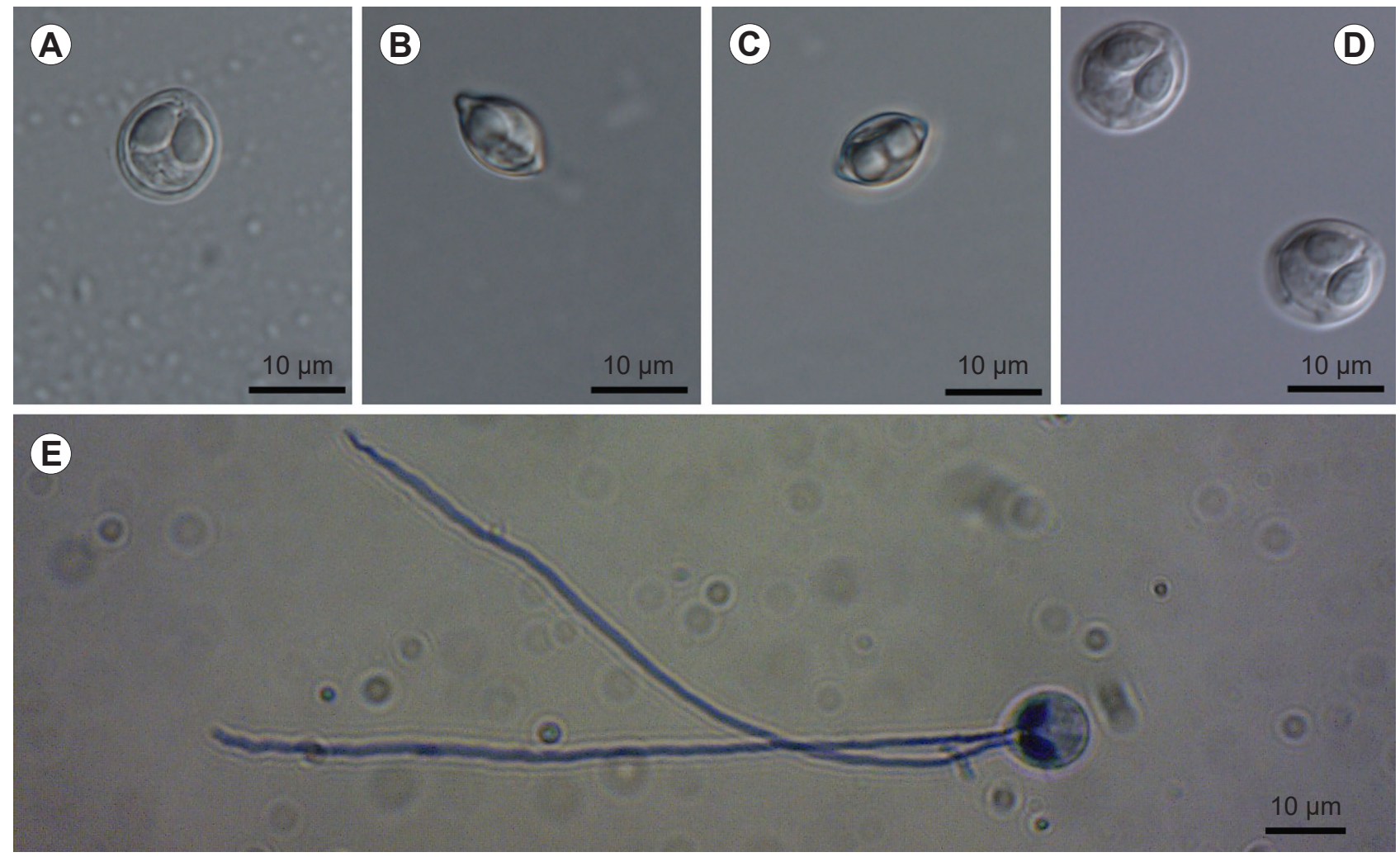

Fig. 2. Spores of Myxobolus taibaiensis sp. n. from Cyprinus carpio Linnaeus. A - frontal view; B - lateral view; C - apical view; $\mathbf{D}$ - folds on the posterior end of spores; $\mathbf{E}$ - spore with extruded polar filaments stained with Diff-Quik.

\section{Myxobolus taibaiensis sp. n.}

ZooBank number for species:

urn:Isid:zoobank.org:act:39549CFE-6D3D-451E-87DF-EFE0B4C83623

Morphological description. Plasmodia ellipsoidal, $1.7-2.9 \mathrm{~mm}$ in length and $0.9-1.7 \mathrm{~mm}$ in width $(\mathrm{n}=20)$. Mature spores ellipsoidal in frontal view and lemon-like in lateral and apical view (Figs. 1B, 2A-C). Spores 10.2-11.2 $(10.8 \pm 0.2)$ in length, 9.1-9.9 $(9.6 \pm 0.2)$ in width and $6.1-6.6(6.3 \pm 0.1)$ in thickness $(\mathrm{n}=50)$. Spore valves smooth and symmetrical (Fig. 3). Polar capsules pyriform, equal in size, situated on anterior end of spores, slightly converging anteriorly, 4.4-5.4 $(5.0 \pm 0.2)$ in length and $3.2-3.6(3.4 \pm 0.1)$ in width, occupying half body of spores.
Polar filaments four to five turns, perpendicular to capsule length. Polar filament up to 106 long after completely extruded, about tenfold of spores length (Fig. 2E). No folds on posterior end of mature spores, but three to four folds clearly visible in some spores (Fig. 2D).

Type host: Common carp Cyprinus carpio Linnaeus (Cyprinidae).

Site of infection: The circular muscle layer of inner intestinal wall.

Prevalence : $25 \%(5 / 20)$.

Type locality: Lake Taibai, Huangmei Country, Hubei Province, China (2956'05"N; $\left.115^{\circ} 47^{\prime} 28^{\prime \prime} \mathrm{E}\right)$.

Type material: Syntype specimens of spores in glycerin gelatin, Diff-Quik stained slide and H \& E stained section deposited in the Laboratory of Fish Diseases, Institute 
of Hydrobiology, Chinese Academy of Science, Acc. No. MTR20151208. The partial 18S rDNA sequence was deposited in the GenBank under the accession number KU928249.

Etymology: The species is named after type locality, Lake Taibai.

Remarks. Until now, 18 Myxobolus species were found in the intestine of common carp in China. Myxobolus taibaiensis $\mathrm{sp}$. $\mathrm{n}$. can be differentiated from morphologically most similar species (Table 1), as follows. The new species can be distinguished from M. cyprinicola Reuss, 1906 and M. rotundatus Achmerov, 1956 by the different shape of the anterior end of spores (tapered $v s$ round). In addition, $M$. cyprinicola has a bigger iodinophilous vacuole and higher number of turns of polar filaments (7-8 vs 4-5) than that of $M$. taibaiensis. Both, M. rotundatus and M. taibaiensis, infect the inner intestinal wall of common carp, but the former species possesses a smaller polar capsule and the ratio of the width of polar capsules to the length. Sequence similarity of $94 \%$ between $M$. rotundatus and M. taibaiensis further supports that they are two different species. Myxobolus ornatus Achmerov, 1960, M. oviformis Thélohan, 1892 and M. linghuensis Chen, 1954 possess a tapered anterior end in which they resemble the new species. However, M. taibaiensis can be easily distinguished

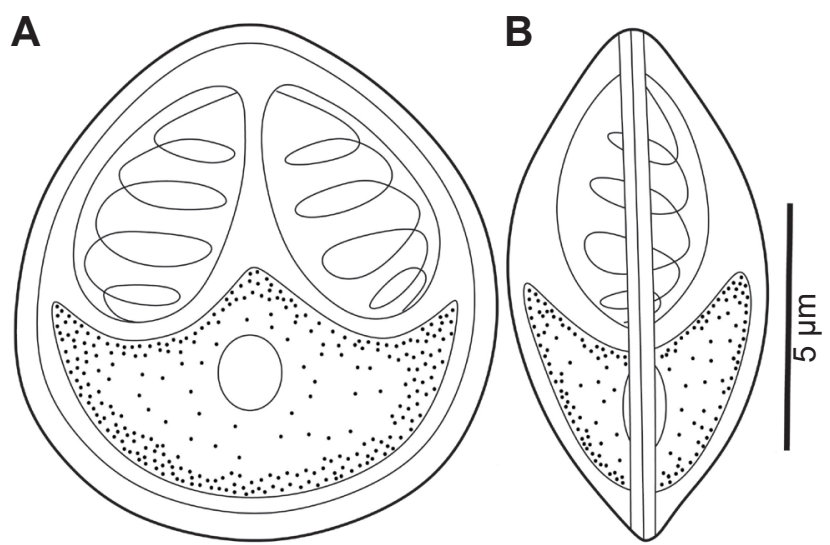

Fig. 3. Schematic drawings of myxospore of Myxobolus taibaiensis sp. n. from Cyprinus carpio Linnaeus. A - frontal view; B - sutural view.

from $M$. ornatus by its lack of a distinct intercapsular appendix. In addition, $M$. taibaiensis can be discriminated from M. oviformis and M. linghuensis by its shorter spore, bigger ratio of the length to the width of spores and fewer turns of polar filaments (4-5 vs 6-7 and 7-8). Furthermore, $M$. oviformis possesses intercapsular appendix and smaller plasmodium $(0.19 \mathrm{~mm} \times 0.18 \mathrm{~mm}$ in diameter $v s$
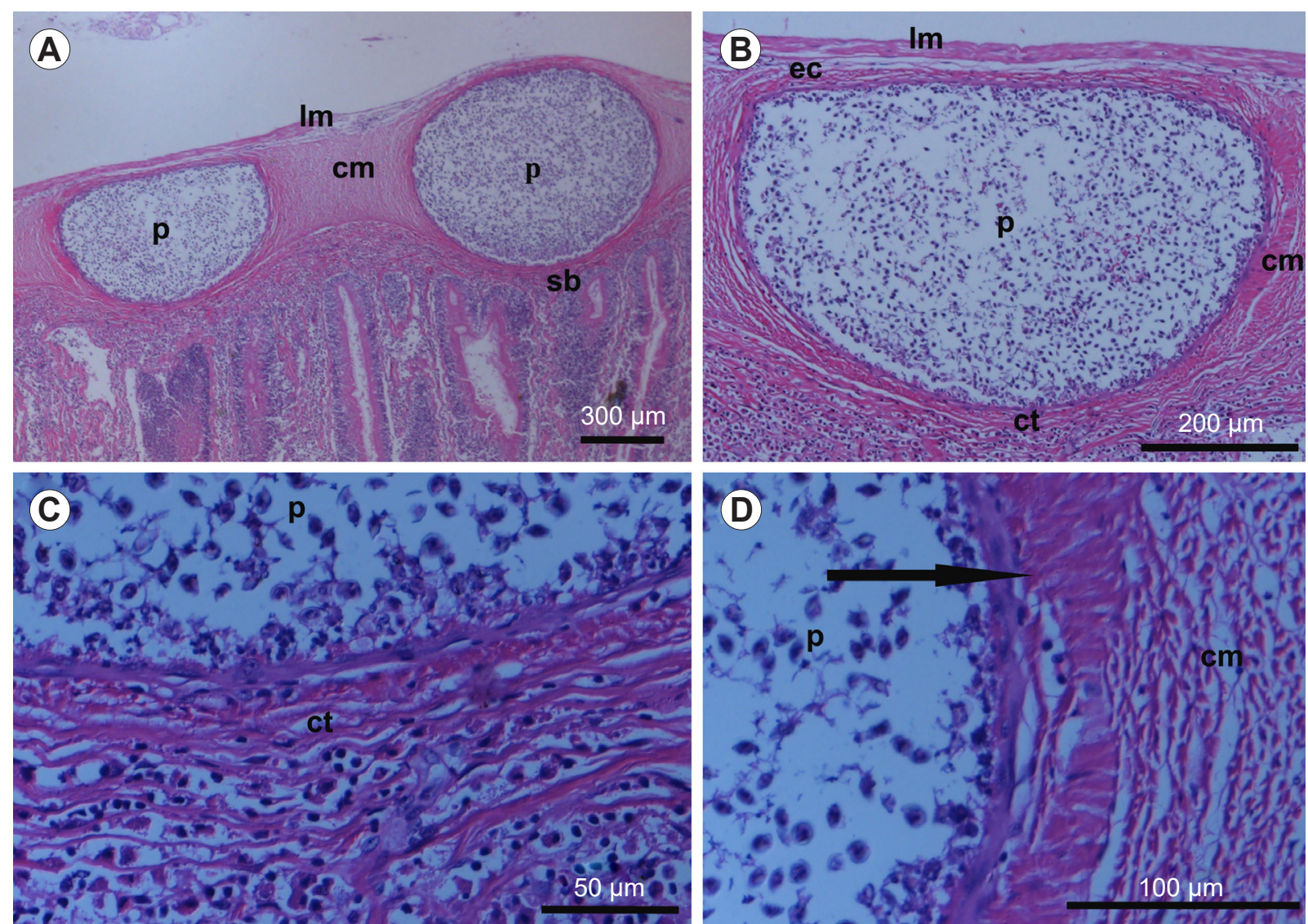

Fig. 4. Histological sections of the intestine of common carp Cyprinus carpio Linnaeus infected by Myxobolus taibaiensis sp. $\mathrm{n}$. A - two plasmodia (p) overgrown by the circular muscle layer $(\mathrm{cm})$ of intestinal wall and bulged into longitudinal muscle layer ( $1 \mathrm{~m}$ ) and submucosa layer (sb); B - smaller plasmodium (p) from Fig. 4A, showing the boundary between longitudinal muscle layer (lm) and circular muscle layer $(\mathrm{cm})$ of intestinal wall of host, ec - ectoplasm; $\mathbf{C}$ - the connective tissue (ct) surrounding plasmodium (p); D - shrinking of adjacent smooth muscle tissues (arrow) caused by mechanical compression of the huge plasmodium (p). 


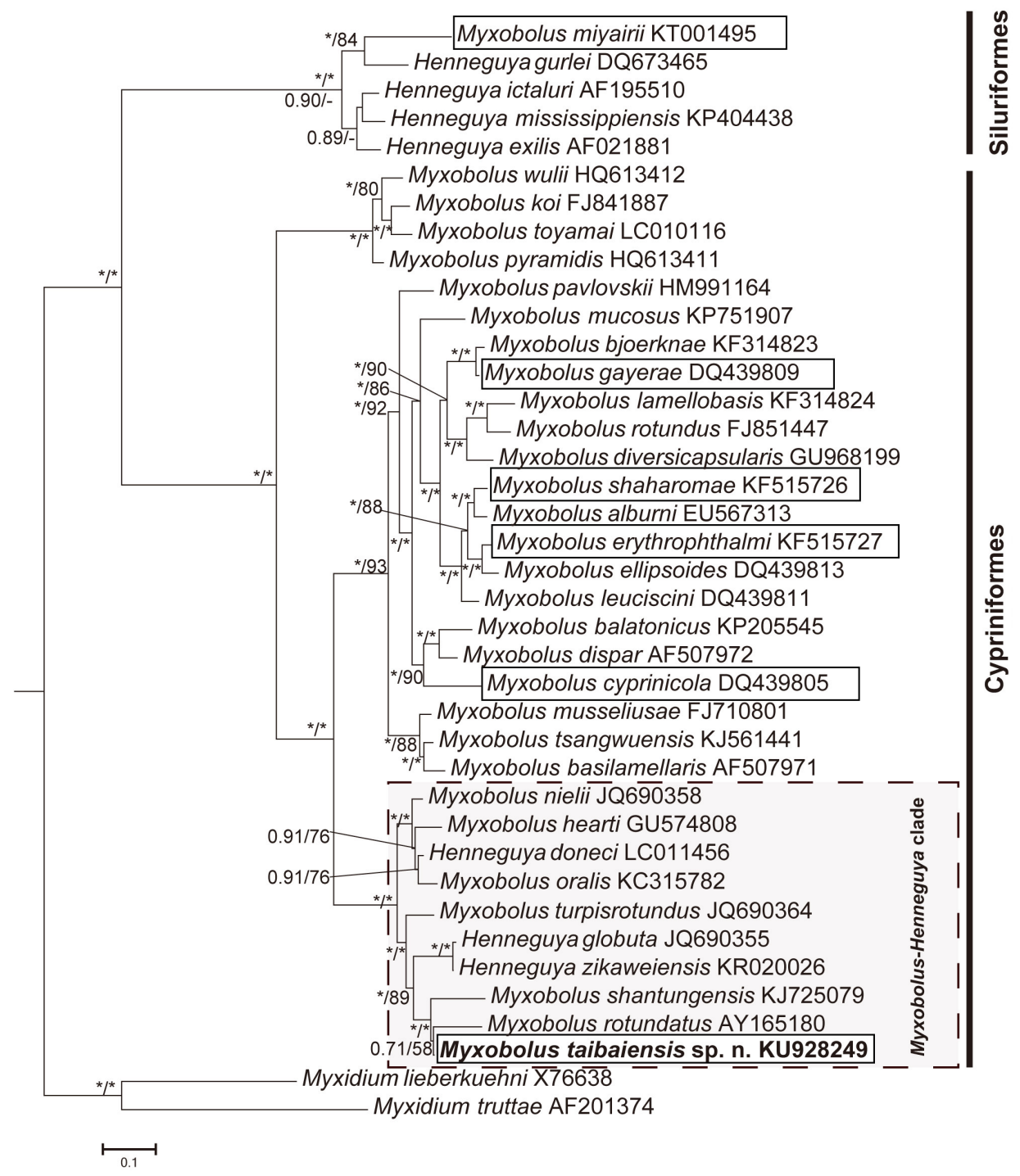

Fig. 5. Phylogenetic tree generated by Bayesian analysis (BI) of the aligned partial SSU rRNA gene sequences of Myxobolus taibaiensis sp. n. and related myxosporeans, rooted at Myxidium lieberkuehni Bütschili, 1882 and Myxidium truttae Léger, 1931. Genbank accession numbers are given adjacent to species names. Numbers at nodes indicate bootstrap support values by BI and maximum likelihood, respectively. Asterisks are shown where values exceeded $95 \%$ and dashes shown for value under $50 \%$. The new species in the present paper is in bold and the intestine-infecting species are within the boxes. The Myxobolus-Henneguya clade, including several common carp-infecting and gibel carp-infecting species, is marked in a dashed box. The order of hosts of all selected species for phylogenetic analysis was pointed out.

1.7-2.9 $\mathrm{mm} \times 0.9-1.7 \mathrm{~mm})$. Folds could be observed easily on the posterior end of M. taibaiensis and M. oviformis, but, their shape is different (V shape $v s$ round shape).

Histopathology. Large plasmodia of ellipsoidal shape started their development in the circular muscle layer of the intestinal wall of common carp (Fig. 4A,B). Ectoplasm of the plasmodia constituted an intensive eosinophilic wall material (Fig. 4B). Plasmodia were surrounded by a layer of connective tissues (Fig. 4A-D) where collagen fibres and large amounts of nuclei of fibroblasts were observed (Fig. 4A-C). The development of plasmodia was asynchronous and produced significant mechanical compression of adjacent tissues, even bulging into the intestinal mucous layer. The involved circular muscle was remarkably thicker than that of unaffected tissues (Fig. 4A,B,D).
No distinct inflammatory response was observed in the infection focus.

Molecular characterisation. A partial SSU rDNA sequence obtained for $M$. taibaiensis was 1737 bp long including regions corresponding to forward and reverse primers. The sequence containing $46.69 \%$ GC bases, was deposited in the GenBank under accession number KU928249. A BLAST search indicated that this sequence was not identical to any myxosporean sequences available in GenBank, but showed high similarity to the following species: Myxobolus shantungensis Hu, 1965 (KJ725079, 96\% over 947 bp), Henneguya doneci Schulman, 1962 (LC011456, 95\% over 1679 bp), M. nielii (Nie et Li, 1973) (JQ690358, 95\% over 1649 bp), M. turpisrotundus Zhang, Wang, Li et Gong, 2010 (JQ690364, 94\% over 1633 bp), M. hearti 
Table 1. Morphological comparison of spore of Myxobolus taibaiensis sp. n. with similar species; all measurements in micrometres, minimum-maximum with mean $( \pm \mathrm{SD})$ in parentheses.

\begin{tabular}{|c|c|c|c|c|c|c|c|c|}
\hline Species & $\begin{array}{l}\text { Site of } \\
\text { infection }\end{array}$ & Shape & Length of spores & $\begin{array}{l}\text { Width of the } \\
\text { spores }\end{array}$ & $\begin{array}{c}\text { Thickness of } \\
\text { spores }\end{array}$ & $\begin{array}{l}\text { Length of } \\
\text { polar capsule }\end{array}$ & $\begin{array}{c}\text { Width of } \\
\text { polar capsule }\end{array}$ & CPF Reference \\
\hline & & & & & 6.0 & 4 & $.5)$ & $7-8 \mathrm{C}$ \\
\hline linghuensis $\mathrm{Ch}$ & & oval & & & & & (.8) & $7-8 \mathrm{C}$ \\
\hline M. ornatus Achmerov, 1960 & & EL & & $9.0-10.8(9.8)$ & & & & $6-7 \mathrm{Cl}$ \\
\hline M. oviformis Thélohan, 1892 & intestine & oval & $10.8-1$ & 8.4 & $6(6.3)$ & 4.8 & 2.6 & 6-7 Che \\
\hline M. rotundatus Achmerov, 1956 & IW & EL & $9.2-$ & .2) & 7.0 & $4.2-$ & $2.1-$ & 4-5 Ch \\
\hline M. & $\mathrm{v}$ & oval & $\begin{array}{c}10.2-11.2 \\
(10.8 \pm 0.2)\end{array}$ & $\begin{array}{c}9.1-9.9 \\
(9.6 \pm 0.2)\end{array}$ & $\begin{array}{c}6.1-6.6 \\
(6.3 \pm 0.1)\end{array}$ & $\begin{array}{c}4.4-5.4 \\
(5.0 \pm 0.2)\end{array}$ & $\begin{array}{c}3.2-3.6 \\
(3.4 \pm 0.1)\end{array}$ & 4-5 P \\
\hline
\end{tabular}

IW - intestinal wall; EL - ellipsoidal; CPF - coils of the polar filaments.

Chen, 1998 (GU574808, 94\% over 1619 bp), H. globulata Ye et Wang, 2012 (JQ690355, 93\% over $1621 \mathrm{bp}$ ) and M. rotundatus (AY165180, 94\% over $660 \mathrm{bp}$ ). BI and ML analyses generated trees of highly similar topologies with different support values at some branch nodes. Myxobolus taibaiensis is sister to $M$. rotundatus and then clusters with $M$. shantungensis to form an independent common carp-infecting group within the Myxobolus-Henneguya clade.

\section{DISCUSSION}

Traditional taxonomy of myxosporean parasites depended upon the spore morphology, but the simplicity and plasticity of mature myxospores caused taxonomic problems (Fiala 2006, Liu 2014). A comprehensive approach of combining morphological features, host, tissue tropism and molecular data has been widely accepted to resolve the above problem, especially discriminating morphologically similar species (Liu et al. 2016b). In the present work, M. taibaiensis sp. $\mathrm{n}$. is morphologically difficult to discriminate from $M$. rotundatus (Table 1). Based on morphological differences, including slightly pointed anterior end, bigger polar filament of $M$. taibaiensis, we thought that these two species are different, even though they both infect the inner intestinal wall of common carp. However, their sequence similarity of only $94 \%$ can be thought to be beyond the intraspecies variation (typically $>2 \%$ intraspecific SSU sequence difference). Therefore, M. taibaiensis is molecularly different from $M$. rotundatus.

Tissue specificity has been considered a very important criterion for myxosporean identification, especially species of Myxobolus. (Molnár 2002, Fiala 2006). About 60 among more than 800 species of Myxobolus were found to infect fish intestine (Eiras et al. 2005, 2014), but only five species were described by the current approach (Molnár et al. 2006, 2009, Liu 2014, Liu et al. 2016a). These are M. shaharomae Molnár, Eszterbauer, Marton, Cech et Székely, 2009, M. erythrophthalmi Molnár, Eszterbauer, Marton, Cech et Székely, 2009, M. gayerae Molnár, Marton, Eszterbauer et Székely, 2007, M. cyprinicola and M. miyairii Kudoa, 1919. Myxobolus miyairii developed numerous visible plasmodia in the whole intestinal wall of its host, with same tissue tropism as $M$. taibaiensis, but they can be easily differentiated by the morphology of spore, size of plasmodia $(0.32-0.78 \mathrm{~mm} v s 1.7-2.9 \mathrm{~mm} \times 0.9-1.7 \mathrm{~mm})$ and the distantly related fish hosts (Siluriformes vs Cypriniformes). Both $M$. cyprinicola and $M$. taibaiensis infect common carp, but $M$. cyprinicola dwells in the subepithelium of lamina propia rather than circular muscle layer of the intestine and its plasmodia are smaller than those of the latter $(0.7 \mathrm{~mm}$ vs $1.7-2.9 \mathrm{~mm} \times 0.9-1.7 \mathrm{~mm})$. Myxobolus shaharomae, M. erythrophthalmi and M. gayerae have not been reported from China. Among them, the plasmodia of $M$. shaharomae and M. erythrophthalmi develop in the blood vessel whereas $M$. gayerae in the propia and submucosa layers of the intestinal wall of chub Squalius cephalus (Linnaeus), surrounded by the loose connective tissues.

The present phylogenetic analysis further demonstrates that all of these six intestine-infecting species of Myxobolus are evolutionally distant. Our result also support the previous conclusion that tissue specificity of sporulation can truly indicate evolutionary relationship (Molnár et al. 2006, 2009), because M. taibaiensis and M. cyprinicola, with different tissue tropism, appear in two different clades. Interestingly, $M$. shantungensis showed close genetic affinity with $M$. taibaiensis, although $M$. shantungensis was reported from gill arches of common carp and is morphological different from the new species. However no detailed data on tissue tropism of $M$. shantungensis are available.

The increasing number of reports of Henneguya-like spores within the plasmodia of Myxobous species provides strong evidence that these two genera have close evolutionary relationships (Liu et al. 2010, 2016a). Our results also show that $M$. taibaiensis clusters within the Myxobolus-Henneguya clade among which all species infect common carp and gibel carp, Carassius auratus gibelio Bloch.

In summary, the present work further evidences that molecular data are important for the identification of myxosporean species and M. taibaiensis was proved to be a new species distinguished from congeners by combining morphological, ecological and molecular data.

Acknowledgements. The present work was financially supported by Jiangsu Province Fund of Sciences (BK2012240), Jiangsu Fishery Project (D2015-11) and Chinese Natural Science Fund (31411130191, 31472296). 


\section{REFERENCES}

Atkinson S., Bartošoví P., Whipps C.M., Bartholomew J.L. 2015: Approaches for characterizing myxozoan species. In: B. Okamura, A. Gruhl and J.L. Bartholomew (Eds.), Myxozoan Evolution, Ecology and Development. Springer International Publishing, Cahm, pp. 111-123.

Chen Q.L., Ma C.L. (Eds.) 1998: [Myxozoa: Myxosporea.] Science Press, Beijing, 993 pp. (In Chinese.)

Dong C.F., Li X.Z., Weng S.P., Xie S.X., He J.G. 2013: Emergence of fatal European genotype CyHV-3/KHV in mainland China. Vet. Microbiol. 162: 239-244.

Dyková I., Fiala I., Nie P. 2003: New data on Myxobolus longisporus (Myxozoa: Myxobolidae), a gill infecting parasite of carp, Cyprinus carpio haematopterus, from Chinese lakes. Folia Parasitol. 50: 263-268.

Eiras J.C., Molnár K., Lu Y.S. 2005: Synopsis of the species of Myxobolus Bütschli, 1882 (Myxozoa: Myxosporea: Myxobolidae). Syst. Parasitol. 61: 1-46.

Eiras J.C., Zhang J.Y., Molnár K. 2014: Synopsis of the species of Myxobolus Bütschli, 1882 (Myxozoa: Myxosporea: Myxobolidae) described between 2005 and 2014. Syst. Parasitol. 88: $11-36$.

Fiala I. 2006: The phylogeny of Myxosporea (Myxozoa) based on small subunit ribosomal RNA gene analysis. Int. J. Parasitol. 36: $1521-1534$.

Guindon S., Dufayard J.F., Lefort V., Anisimova M., HordiJK W., Gascuel O. 2010: New algorithms and methods to estimate maximum likelihood phylogenies: assessing the performance of PhyML 3.0. Syst. Biol. 59: 307-321.

HaLl T.A. 1999: BioEdit: a user-friendly biological sequence alignment editor and analysis program for Windows 95/98/NT. Nucl. Acids Symp Ser. 41: 95-98.

JIN H.B. 2007: [Innovative culturing of lake method making highyield fish product.] Fish. Guide Rich. 8: 14-15. (In Chinese.)

Lin J.R., Chen Y.D., Guo R. 2014: [China Fishery Statistics Yearbook.] China Agriculture Press, Beijing, 521 pp. (In Chinese.)

LiU Y. 2014: [Taxonomy of the genus Myxobolus (Myxozoa: Myxosporea) with identification of some Myxobolus species in China.] Huazhong Agriculture University, PhD thesis, 126 pp. (In Chinese.)

Liu X.H., Zhang J,Y., Batueva M.D., Voronin V.N. 2016a: Supplemental description and molecular characterization of Myxobolus miyairii Kudo, 1919 (Myxosporea: Myxobolidae) infecting intestine of Amur catfish (Silurus asotus). Parasitol. Res. 115: $1547-1556$.

Liu Y., Whipps C.M., Gu Z.M., Huang M.J., He L.Y., Molnár K. 2013: Myxobolus musseliusae (Myxozoa: Myxobolidae) from the gills of common carp Cyprinus carpio and revision of Myxobolus dispar recorded in China. Parasitol. Res. 112: 289-296.

Liu Y., Whipps C.M., Gu Z.M., Zeng L.B. 2010: Myxobolus turpisrotundus (Myxosporea: Bivalvulida) spores with caudal appendages: investigating the validity of the genus Henneguya with morphological and molecular evidence. Parasitol. Res. 107: 699-706.

Liu X.H., Yuan S., ZhaO Y.L., Fang P., Chen H., Zhang J.Y. 2016b: Morphological and molecular characterization of Myxobolus sheyangensis $\mathrm{n}$. sp. (Myxosporea: Myxobolidae) with in- tralamellar sporulation in allogynogenetic gibel carp Carassius auratus gibelio (Bloch) in China. Parasitol. Res. 115: 3567-3574.

Lом J., DyкоvÁ I. 2006: Myxozoan genera: definition and notes on taxonomy, life-cycle terminology and pathogenic species, Folia Parasitol. 53: 1-36.

MolnÁR K. 2002: Site preference of fish myxosporeans in the gill. Dis Aquat Org. 48: 197-207.

Molnár K., Eszterbauer E., Marton S., SzéKely C. 2009: Myxobolus erythrophthalmi sp. n. and Myxobolus shaharomae sp. n. (Myxozoa: Myxobolidae) from the internal organs of rudd, Scardinius erythrophthalmus (L.), and bleak, Alburnus alburnus (L.). J. Fish Dis. 32: 219-231.

Molnár K., Marton S., Eszterbauer E., Székely C. 2006: Comparative morphological and molecular studies on Myxobolus spp. infecting chub from the River Danube, Hungary, and description of M. muellericus sp. n. Dis. Aquat. Org. 73: 49-61.

PAGE R.D.M. 1996: TREEVIEW: an application to display phylogenetic trees on personal computers. Comput. Appl. Biosci. 12: $357-358$.

Posada D. 2008: jModelTest: phylogenetic model averaging. Mol. Biol. Evol. 25: 1253-1256.

Ronquist F., Huelsenbeck J.P. 2003: MrBayes 3: Bayesian phylogenetic inference under mixed models. Bioinformatics 19: $1572-1574$.

Székely C., Atkinson S.D., Molnár K., Egyed L., Guyányi A., СеCH G. 2016: A synopsis of records of myxozoan parasites (Cnidaria: Myxozoa) from shrews, with additional data on Soricimyxum fegati from common shrew Sorex araneus in Hungary and pygmy shrew Sorex minutus in Slovakia. Folia Parasitol. 63: 021

Tamura K., Stecher G., Peterson D., Filipski A., Kumar S. 2013: MEGA6: Molecular Evolutionary Genetics Analysis version 6.0. Mol. Biol Evol. 30: 2725-2729.

Thompson J.D., Gibson T.J., Plewniak F., Jeanmougin F., Higgins D.G. 1997: The CLUSTAL-X window interface: flexible strategies for multiple sequence alignment aided by quality analysis tools. Nucl. Acids Res. 25: 4876-4882.

Whipps C.M., Adlard R.D., Bryant M.S., Lester R.J.G., Findlay V., Kent M.L. 2003: First report of three Kudoa species from eastern Australia: Kudoa thyrsites from mahi mahi (Coryphaena hippurus), Kudoa amamiensis and Kudoa minithyrsites $\mathrm{n}$. sp. from sweeper (Pempheris ypsilychnus). J. Euk. Microbiol. 50: 215-219.

Yokoyama H., Inoue D., Kumamaru A., Wakabayashi H. 1997: Myxobolus koi (Myxozoa: Myxosporea) forms large- and small-type "cysts" in the gills of common carp. Fish. Pathol. 32: 211-217.

Zhai Y.H., Gu Z.M., Guo Q.X., Wu Z.Z., Wang H.M., Liu Y. 2016: New type of pathogenicity of Thelohanellus kitauei Egusa \& Nakajima, 1981 infecting the skin of common carp Cyprinus carpio L.. Parasitol. Int. 65: 78-82.

Zhang Y.F., Meng L.J., Zhang W.L., Hao D.X., Liu P., Zhang X.J. 2010: [The pathogenic bacterium of bacterial septicemia in common carp.] Fish. Sci. 29: 287-290. (In Chinese.)

Received 6 June 2016

Accepted 10 November 2016

Published online 10 January 2017

Cite this article as: Liu X., Hua C., Zhang Q., Zhao Y., Zhang D., Zhang J. 2017: Myxobolus taibaiensis sp. n. (Myxozoa: Myxosporea) infecting the intestinal wall of common carp Cyprinus carpio Linnaeus in China. Folia Parasitol. 64: 001. 